\title{
Vaisenhuset og Blaagaard Skolelærerseminarium: Forbindelsen mellom to lærdomsmiljø i København omkring 1795
}

\author{
Randi Skjelmo
}

\begin{abstract}
Vaisenhuset and Blaagaard teacher education institute: The connection between two learning institutions in Copenhagen about 1795

Vaisenhuset (The Orphan House) in Copenhagen was established after the Nordic War (1700-1720) to take care of and educate orphans. The institution soon became a centre for the Pietists in Denmark. Blaagaard Institute was initiated by The Great School Commission and became the first government-financed teacher education in Denmark. It was established 1791 inspired by Enlightenment ideas. When The Orphan House was totally destroyed during a fire 1795, the initiative was taken to amalgamate with Blaagaard. This article answers the following questions: What kind of institution was The Orphan House in 1795? What kind of institution was Blaagaard? How was care and education for poor and orphan girls and boys planned to be realised in a new institution? Which future role was intended for The Orphan House in relation to Blaagaard?

\section{Keywords}

eighteenth century, orphans, social and educational ideas, teacher education, Copenhagen

1700-tallet, foreldreløse jenter og gutter, sosial og pedagogisk tenkning, lærerutdanning, København
\end{abstract}

\section{Innledning}

Natten mellom d. 5te og 6te Juni sov Børnene i deres bedste Klæder med en Byldt Linned under Hovedet i Gangene. De vigtigste Documenter og samtlige Regnskaber bleve lagte i Sække og bragte til Gudes Moders Huus i Vigants Gade. Den 6te Juni efter Kl. 12 forlod Børnene Vaisenhuset og gik til Blaagaard, ledsagede av Læremødrene og Lærerne, hvilke bar Alterstagerne og de hellige Kar. [...] Næste Dag besøgte Gude Blaagaard og fandt Børnene fornøiende paa det nye Sted. ${ }^{1}$

Hendelsen som her refereres, fant sted under den store bybrannen i København på forsommeren 1795. Den oppsto om ettermiddagen 5. juni; en fjerdedel av ho vedstadens bygninger ble lagt $\mathrm{i}$ aske og 6000 mennesker ble gjort husløse i løpet av to

1 A. Exner, Efterretninger om Det Kongelige Vaisenhus (København: J.H. Schultz, 1881), 80-1.

Randi Skjelmo is Associate Professor of Pedagogy at the Department of Education, University of Tromsø, The Arctic University of Norway.

Email: randi.skjelmo@uit.no 
døgn. ${ }^{2}$ Barna talte mellom 100 og 120 og var tilhørende på Vaisenhuset, en institusjon for foreldreløse og fattige jenter og gutter, beliggende i sentrum av København. Med flammer som truet i nærheten, hadde barna ikke gått til sengs på sovesalene som vanlig, men lagt seg fullt påkledd i gangene. Om brannen tiltok, kunne de dermed raskt evakueres. Da barna ble bragt i sikkerhet neste dag, skjedde det ved at de sammen med sine foresatte gikk til fots til Blaagaard. Stedet lå utenfor byen og huset det nyopprettede skolelærerseminariet for helstaten Danmark-Norge. Vaisenhuset ble totalskadd i brannen og i arbeidet med å finne ordninger for den videre driften framkom forslaget om en sammenslåing med Blaagaard. Den midlertidige samlokaliseringen av de to lærdomsmiljøene kom til å bli den alminnelige ordning i tiden mellom 1795 og 1799.

Fokuset i denne artikkelen ligger på den forening av de to institusjoner, Vaisenhuset og Blaagaard, som fant sted i etterkant av brannen i 1795. De spørsmål artikkelen søker å gi svar på er:

1. Hva slags institusjon var Vaisenhuset omkring 1795?

2. Hva slags institusjon var det nyopprettede Blaagaard Skolelærerseminarium?

3. Hvordan var omsorg og utdanning for fattige og foreldreløse jenter og gutter tenkt realisert gjennom en forening av de to institusjoner?

4. Hvilken rolle var Vaisenhuset tiltenkt i forhold til det nyetablerte Blaagaard skolelærerseminarium?

\section{Teoretisk og metodologisk tilnærming}

For å klargjøre hvilke muligheter som lå i en forbindelse utover det rent organisatoriske, er også perioden som gikk forut for 1795 betonet. Teoretisk knytter artikkelen an til Ingrid Markussens arbeid Til Skaberens Ære, Statens Tjeneste og Vor egen Nytte og Ida Bulls nyskrevne arbeid Kunnskap - hver etter sin stand og sitt kjønn. Bull gir en framstilling av den utdanning som fantes i byene på 1700-tallet og tidlig 1800-tall i Norge. Et av spørsmålene hun stiller er om alle skulle lære det samme. Hun konkluderer med, at den utdanning som ble gitt, var tilpasset den enkeltes stand og kjønn. Selv om utdanning i løpet av syttenhundretallet fikk et økt omfang, konkluderer Bull med at den ikke ble et middel for å endre standstilknytning. Også hos Markussen står kjønn og stand sentralt. Med utgangspunkt i leseforskning har hun avdekket forbindelser mellom reformer innenfor landbruk og skole. Hun trekker inn pietismen og kameralismen som idegrunnlag. Blant kameralistene var siktemålet å oppnå økonomisk utvikling gjennom landbruk og manufakturindustri.

Primærkildene som ligger til grunn for denne artikkelen er framkommet gjennom studier i Misjonskollegiets arkiv ved Rigsarkivet i København. Det er å anta at det også i arkivene til Danske Kanselli og Den Store Skolekommisionen finnes materiale som ytterligere kan belyse forskningsspørsmålene. Studier i Misjonskollegiets arkiv har vært motivert av kunnskapssøken om tidlig lærerutdanning i nordområdene, deriblant de tidlige seminarier i Trondheim i Norge for perioden 1717-1732. Det ble av den danskfødte biskop Schønheyder tatt initiativ til et seminarium sist på 1700-tallet i Trondheim som skulle samlokaliseres med byens Vaisenhus. ${ }^{3}$ Den dans-

2 Den Store Danske, "Københavns brande," http://www.denstoredanske.dk/Danmarks_geografi_og historie/Danmarks_historie/Danmark_1536-1849/K\%C3\%B8benhavns_brande.

3 Elizabeth B. Jacobsen, "Schönheyders Skolemester-Seminarium i Trondheim: Et forsøk på organisert skoleholderutdannelse ved århundreskiftet 1800" (Hovedoppgave i historie, Universitetet i Trondheim, 1992). 
ke helstatspolitikken satte imidlertid en stopper for en slik utvikling. Misjonskollegiets arkiv ble oppbevart i Vaisenhuset og store deler anses å ha gått tapt ved brannen i 1795. Av sitatet innledningsvis ser vi hvordan deler av arkivet ble reddet. Blant dette var stillingsinstrukser. Anvendt i artikkelen er to trykte instrukser fra Vaisenhuset, den ene for informatorer, som var de mannlige lærere, den andre for læremødre, som var kvinnelige ansatte. ${ }^{4}$ Informatorer og læremødre var stillingskategorier, og det var disse ansatte som hadde den meste og tetteste kontakten med barna. Helt fra oppstarten hadde det vært vanlig med trykte utgivelser av dokumenter som gjaldt den daglige driften. Det framgår ikke av instruksene når disse var blitt vedtatt eller trykket, men begge er underskrevet året 1791. Gjennom underskriftene får vi vite hvem som var tilsettingsmyndighet og vi får vite navnet på de ansatte. Instruksene er normative kilder, som belyser hvordan virksomheten var tenkt å fungere. De er omfattende og detaljerte; instruksen for informatorer inneholdt 36 paragrafer, instruksen for læremødre 29 paragrafer. De viser at det var et tydelig stillingshierarki, informatorene og læremødrene var overordnet tjenestefolkene og underlagt husets prest. Informatorer og læremødre var ment å ha oppsyn med barna størsteparten av dagen, delta aktivt $i$ oppdragelsen og ha ansvar for at daglig rutiner ble fulgt. Instruksene gir innblikk i arbeidsområdene til de ansatte som var tettest på barna og blir dermed betydningsfulle som kilde til kunnskap.

I materialet inngår videre to brev fra førstelærer ved Blaagaard seminar, J. Chr. G. Clausen. ${ }^{5}$ Begge brevene er et forsvar for å bevare Vaisenhuset gjennom en sammenslåing med Blaagaard etter brannen i 1795. Det var nemlig framkommet forslag om å avvikle Vaisenhuset, fra aktører som mente at det ikke svarte til sin hensikt. ${ }^{6}$ Vi har innledningsvis sett at barna ble innlosjert i bygningen til lærerseminariet allerede mens brannen pågikk. Det som i utgangspunktet var en nødløsning har etter hvert blitt å betrakte som en midlertidig ordning. Det ble nedsatt en kommisjon for å utrede den videre driften av Vaisenhuset, og et av forslagene som framkom var en permanent sammenslåing med Blaagaard. Begge brevene fra førstelærer Clausens er håndskrevne. ${ }^{7}$ Det første er datert 18. september 1795 og er et begrunnet forslag fra Clausen om å forene Vaisenhuset med Blaagaard. Transkribert utgjør brevet sju sider. ${ }^{8}$ Det andre brevet er skrevet 2. november samme år og stilet til de "Høystærede

4 Instrux for samtlige Informatorer ved det Kongelige Waysenhuus, underskrevet 19de Januarii 1791, Missionskollegiet og Directionen for Vajsenhuset 1721-1868, Diverse dokumenter, 234 Missionskollegiets arkiv (MK), Rigsarkivet i Danmark (RAD); Instrux for Lære-Mødrene ved det Kongelige Waysenhuus, underskrevet 31te Martii 1791, Missionskollegiet og Directionen for Vajsenhuset 1721-1868, Diverse dokumenter 7, 234, MK, RAD .

5 Forslag fra J. Chr. G. Clausen, 18de Sept, 1795, Missionskollegiet og Directionen for Vajsenhuset 1721-1868, Diverse dokumenter 7, 234 MK, RAD.

6 Statsfysikus Dr. Mangor innga 2. juli 1795 et forslag til Danske Kanselli om ikke å gjenoppføre Vaisenhuset. Han anklaget barna for atskillige laster, de var bleke og forknyttede til tross for god og tilstrekkelig føde, de kledtes for godt, spiste for godt, gikk for tidlig til sengs, hadde lov til å vrake maten og de kostet for mye. Ved å sette barna i privat pleie hos bønder og håndverkere mente Magnor at Vaisenhusets Fond kunne bekoste oppdragelsen av 720 barn, i motsetning til de 120 som hadde plass i Vaisenhuset. Halvparten av barna fra København kunne få sin oppdragelse på Blaagaard, dels for å utgjøre en skole til øvelse for seminaristene, dels for "endnu at gøre nogle Eksperimenter med den sammendyngede Opdragelse"; Chr. Ottesen, Det Kgl. Vajenhus gennem to hundrede aar (København: Haase \& Søn, 1927), 84.

7 Forslag fra Clausen, 18de Sept: 1795, 234 MK, RAD; Forslag fra Clausen, 2 Nov, 1795, Missionskollegiet og Directionen for Vajsenhuset 1721-1868, Diverse dokumenter 7, 234, MK, RAD.

8 Forslag fra Clausen, 18de Sept, 1795, 234 MK, RAD. 
Herrer Medlemmer i Commissionen". ${ }^{9}$ Den kommisjonen som her er adressat, er sannsynligvis den som var blitt nedsatt for å utrede den videre driften av Vaisenhuset etter brannen. Her var Clausen selv medlem. Brevet innledes med en sides meddelelse og er vedlagt kopi av Clausens forslag av 18. september om en sammenslåing av de to institusjonene. Han ber i dette andre brevet kommisjonen ta stilling til forslaget om å forene Vaisenhuset og Blaagaard. Forslaget og argumentasjonen i brevet var ikke bare et pragmatisk løsningsforslag i en vanskelig situasjon, men viser hvilken sosial og pedagogisk tenkning som lå til grunn for den foreslåtte organiseringen. Dette gjaldt både allmennutdanning og yrkesforberedelse for jenter og gutter, samt utdanning for seminarister. Dokumentene viser også hvordan sosial og pedagogisk tenkning faller sammen. De gir tilgang til skolepolitiske ideer sist på syttenhundretallet som inkorporerte det sosiale perspektivet med tilgang til utdanning for fattige barn og barn uten forsørgere. De gir også innblikk i tidlig lærerutdanning. Vi får innblikk i hvilke tanker om undervisning og om organisering som var felles for de to institusjonene og hva slags endringer som var ønskelige. Gjennom Clausens brev blir det mulig å knytte forbindelse mellom undervisningen av jentene og guttene ved Vaisenhusets skole og undervisningen av seminaristene og til rekruttering av kandidater til seminaret. Blant kildene er også en kongelig advarsel mot å innføre eller trykke bøker som Vaisenhuset hadde monopol på. ${ }^{10}$ Vaisenhuset baserte sine inntekter på blant annet apotekdrift og trykkeprivilegier. Av skrivet framgår det hvordan disse privilegiene var viktige som økonomiske vilkår for undervisningen ved Vaisenhusets skole.

Også det nyskrevne verket Dansk skolehistorie er en kilde til kunnskap. Det gjelder både første bind Da loereren holdt skole: Tiden før 1780 og andre bind Da skolen tog form: Tiden 1780-1850. For utfyllende opplysninger om Blaagaard er anvendt Ingrid Markussens framstilling i Dansk loereruddannelse bind 1. Denne inngår i et trebindsverk om dansk lærerutdanning som omhandler perioden fra opprettelsen av Blaagaard og fram til nyere tid. I tillegg er anvendt A. Exners bok Efterretninger om Det Kongelige Vaisenhus og Chr. Ottesens Det Kgl Vajsenhus gennem to hundrede aar. Exner var teologisk kandidat og lærer ved Vaisenhuset fra 1854, boken omhandler perioden fra Vaisenhuset ble igangsatt i $1727 \mathrm{og}$ fram til 1881. Ottesens bok utkom etter at han i mer enn 30 år hadde arbeidet i Vaisenhusets arkiv og går fram til 1927. Begge framstillingene er godt belagt med kilder og er viktig bidrag til kunnskap om virksomheten både i tidsrommet omkring 1795 og i tiden forut for de hendelser som aktualiserte sammenslåingen.

\section{Opprettelse av et Vaisenhus i København}

Danmark hadde i årene fram mot 1720 vært preget av spørsmålet om hva som kunne gjøres for de fattige barna. Problematikken hadde fătt økt aktualitet som følge av den store nordiske krig (1709-1720). Mange familier hadde mistet sine forsørgere som direkte følge av krigshandlinger, og en rekke barn var blitt foreldreløse som følge av sykdomsepidemier. Det eksisterte på denne tiden et fattigvesen i København som blant annet hadde innredet en bygning til forpleining av foreldreløse barn. Samtidig

9 Forslag fra Clausen, 2 Nov, 1795, 234 MK, RAD.

10 Skriv fra Kong Christian 6. vedrørende trykkeprivilegier, 6te Maj 1740, Fundas med senere ændringer, 235 Det Kgl. Vajsenhus 1720-1826, RAD. 
$ø$ kte antall hittebarn og nyfødte barn som var blitt forlatt. ${ }^{11}$ Forslaget om et Vaisenhus hadde vært lansert flere ganger i løpet av krigen, men det var først i etterkant av denne at institusjonen kom nærmere en realisering. Det skjedde gjennom en meddelelse fra kongen til Misjonskollegiet, om at han ville bevilge et årlig beløp til et Vaisenhus. Misjonskollegiet skulle stå for etableringen og overtilsynet med virksomheten. ${ }^{12}$

I forkant fungerte Misjonskollegiet som et departement med ansvar for misjonsvirksomheten i Trankebar i India, blant samene i det nordlige Norge og blant inuittene på Grønland. Misjonskollegiet var blitt etablert i 1714 for å få den danske trankebarmisjonen i ordnede former, etter at det hadde oppstått konflikter mellom misjonærene fra Halle og ledelsen for det Ostindiske handelskompaniet. ${ }^{13}$ Exner anvender ikke betegnelsene indre og yte misjon, men skiller mellom "Hedningene i Ostindien" og "Finmarken, der dog kaldtes et christent Land". ${ }^{14}$ I forlengelsen av dette viser han at også oppdragelsen av forlatte barn i et vaisenhus kunne oppfattes som en slags misjonsvirksomhet mellom hedninger i et kristent land; "Det er ved denne Forbindelse til Missionen, at Vaisenhuset fra først af erholdt sin religiøse Besegling og Indvielse, og fik sin Opdragelse grundlagt paa religiøse Motiver". ${ }^{15}$

Igangsettelsen og driften av Vaisenhuset skulle nå komme i tillegg til oppgavene i India, Norge og Grønland. Til formålet ga kongen en bygning på Nytorv i København som hadde huset det tidligere ridderlige akademi. ${ }^{16}$ På Vaisenhuset skulle barna få et hjem, hvor de utover forpleining også skulle få oppdragelse og undervisning. I tråd med pietistisk tankegang skulle barna opplæres i den evangeliske kristendomsoppfattelse etter den augsburgske konfesjon, til å tro på Gud og leve etter hans vilje. Jentene skulle få øving i kjøkkenarbeid, spinning, søm og knipling. Med slike kunnskaper og ferdigheter ville de bli i stand til å skaffe seg et utkomme. Guttene skulle få undervisning i historie og geografi, de som hadde anlegg for det fikk også lære matematikk, mekanikk eller lovkunnskap. Guttene ble også gitt anledning til å studere. For guttene var det altså evnene som bestemte hvilken utdanning de fikk, ikke økonomi eller stand. Læremødrene deltok til en viss grad også i undervisningen ved at de lærte jentene opp til ulike former for husstell og håndarbeid og de lærte guttene å strikke strømper. ${ }^{17}$ I tillegg til opplæring og disiplinering, bidro barnas arbeid også til økonomisk utbytte gjennom det arbeid de utførte. Vaisenhuset skulle også ha sin egen kirke med offentlig gudstjeneste og katekisasjon på dansk eller tysk. Siktemålet med virksomheten ved Vaisenhuset var med andre ord todelt, den skulle både frelse den fattige ungdom og skaffe etterslekten bedre livsvilkår. Den endelige åpningen fant sted i $1727 . .^{18}$ Ved igangsettelsen ble det tatt inn 30 barn, 13 jenter og 17 gutter. I løpet av det første året var antallet barn utvidet til 100. Fra oppstarten

11 Ottesen (1927), 15-20

12 Ottesen (1927), 13

13 Randi Skjelmo, "Utdanning av lærere for det nordlige Norge: De tidlige institusjoner i Trondheim 1717-1732," Sjuttonhundratal. Nordic Yearbook for Eighteenth-Century Studies (2013), 44.

14 Exner (1881), 3-4.

15 Ibid., 4.

16 Charlotte Appel og Morten Fink-Jensen, Da loereren holdt skole: Tiden før 1780, bind 1 av Dansk skolehistorie: Hverdag, vilkår og visioner gennom 500 år, red. Charlotte Appel og Ning de Coninck-Smith (Århus: Århus universitetsforlag, 2013), 246.

17 Instrux for Lære-Mødrene 1791, \$13, 234 MK, RAD.

18 Appel og Fink-Jensen (2013), 244. 
bodde der 13 voksne som var tilsatt i ulike stillinger. Fire av disse var informatorer og to var læremødre. På det meste var det omkring 120 barn som bodde i Vaisenhuset.

Vaisenhuset i København var etablert etter modell av Vaisenhuset i byen Halle i Tyskland. Dette hadde teologen og pedagogen August Hermann Francke (16631727) fătt bygd i $1698 .{ }^{19}$ Vaisenhuset representerte da noe helt nytt, tidligere hadde foreldreløse barn blitt anbrakt i de barnehjem som tilhørte tukthusene. Halle ble regnet som pietismens arnested i Tyskland, mens Vaisenhuset i København var sentrum for pietismen i Danmark. ${ }^{20}$ Sammen med den tyske teologen Philipp Jakob Spener (1635-1705) regnes Francke som pietismens grunnlegger. ${ }^{21} 1692$ ble Francke prest og professor i Halle. Som universitetslærer la han særlig vekt på et vitenskapelig-oppbyggelig bibelstudium, og som prest drev han menighetsarbeid og tok seg av fattigpleien. Han grunnla de berømte Franckes stiftelser, og bygningene står ennå som et minnesmerke over virksomheten. Fra å begynne i det små vokste stiftelsene til å omfatte bl.a. fattigskole (1695), to borgerskoler, læreanstalt for fornemme folks barn (1696), latinskole (1697), vaisenhus (1698), bokhandel (1698), boktrykkeri (1701), den ostindiske misjonsanstalt med et stort bibliotek (1705), apotek og bibelanstalt (1710). ${ }^{22}$ Foruten organisatorisk talent la han for dagen pedagogiske evner. Francke tok også initiativ til misjon, og det reiste ut flere misjonærer fra Halle. Også de misjonærene som ble sendt ut av den danske trankebarmisjonen for å virke i India var tyskere fra Franckestiftelsen. For Francke og Halle-pietismen var det viktig at omvendelsen til et sant kristent liv skulle kunne identifiseres som en bestemt og epokegjørende hendelse i den troendes liv.

\section{Vaisenhuset omkring 1795}

Formålet med virksomheten ved Vaisenhuset var "Opbyggelse og Saligheds Befordring, samt danne de unge Børn til nyttige Borgere i Staten." ${ }^{23}$ Informatorene og læremødrene skulle være gode eksempler i ustraffelig vandel, de skulle ha kjærlighet og opptre med en vennlig alvorlighet. De måtte også vokte seg for at de verken i ord eller gjerning ga de små noen forargelse, og oppdragerne ble anbefalt å være innbyrdes enige. ${ }^{24}$ Ved Vaisenhusets skole ble alle, både jenter og gutter undervist i fagene kristendom, regning og skriving. Barna ble inndelt i klasser ut fra alder og evner, slik at en informator tok seg av de som skulle lære å stave, en annen av de som skulle undervises i katekisme, en tredje av dem som skulle lese i Bibelen og lære skriftsteder og en fjerde av de som skulle lære å skrive og regne. En egen paragraf omhandlet straff, og det ble framholdt at korporlig straff burde unngås. ${ }^{25}$ I stedet burde man ty til tiltak som igjensitting, flytte elevene en klasse ned eller skille dem fra de andre. Instruksene viser videre at det var en klar kjønnsdeling på noen områder når det gjaldt undervisning; guttene ble oppfordret til å søke kunnskap utenfor stiftelsen "til det de

19 Ottesen (1927), 15.

20 Appel og Fink-Jensen (2013), 244-5.

21 Store norske leksikon, "August Hermann Francke," http://snl.no/August_Hermann_Francke.

22 Ibid.

23 Instrux for samtlige Informatorer 1791, $\$ 1,234 \mathrm{MK}, \mathrm{RAD}$.

24 Instrux for samtlige Informatorer 1791, \$2, $234 \mathrm{MK}$, RAD; Instrux for Lære-Mødrene 1791, \$2, 234 MK, RAD.

25 Instrux for samtlige Informatorer $1791, \$ 10,234 \mathrm{MK}$, RAD. 
have Lyst og Duelighed til", jentene til å lære hånd- og husgjerning innenfor stiftelsen. ${ }^{26} \mathrm{Vi}$ ser altså helt klart at jenter og gutter ikke hadde de samme mulighetene når det gjaldt hvilken kunnskap det var mulig å søke. Guttene kunne følge sine interesser og anlegg gjennom å søke ut fra institusjonen. Jentene ble opplært til å forsørge seg selv gjennom håndarbeid som strikking, spinning og knipling. De fikk dermed en opplæring som gjorde at de kunne gå inn i manufakturindustrien. Jentene fikk også opplæring i generelt husarbeid som skulle komme til nytte i et fremtidig ekteskap eller i tjeneste for andre.

Man var også opptatt av barnas helse. Det var lege tilknyttet Vaisenhuset, et eget sykeværelse og en kjemmekone skulle holde barna rene for utøy. Barna ble vekket av læremoderen klokken seks om morgenen. ${ }^{27}$ Etter vask og påkledning fulgte reiing av senger, rengjøring og lufting av sovesaler. Læremoderen skulle så, ved hjelp fra et par av de mest voksne og forsiktige av barna "som dertil kan betroes, lader røge med Enebær overalt paa Sovesalene, Gangene og Skolerne". ${ }^{28}$ Klokken kvart på sju skulle alt være ferdig og samtlige barn samles for å følges til morgenbønn klokken sju. Flere av paragrafene omhandlet barnas tøy og sko. Nypussede sko skulle både forlenge brukstiden og inngi et godt førsteinntrykk:

\footnotetext{
Med de Børn, som gaae ud af Stiftelsen, enten til Læremestere eller paa Tegne-Academiet, maa Informatorerne have nøye Opsigt, at de ere skikkelig iførte, samt deres Haar og Skoe ordentlig opsadt og pudset. ${ }^{29}$
}

Undervisning i den kristne lære spilte en sentral rolle. Informator og læremoder fulgte barna til kirken, og i etterkant ble de prøvd i hva de hadde forstått av prekenen. ${ }^{30}$ Informatorene skulle også holde oppsyn med at alle deltok i gudstjeneste og bønn. Forberedelsene på skolen spilte en viktig rolle for det som skulle skje i kirken. Videre gikk høytlesing ved måltidene på omgang blant barna. I forkant hadde de øv på denne lesingen på skolen. I tillegg til morgenbønnen før frokost deltok barna i bønn etter kveldsmaten. Det ble bedt for kongen, direksjonen, stiftelsen og dens støttespillere. ${ }^{31} \mathrm{Vi}$ ser altså at religionen spilte en viktig rolle når det gjaldt å disiplinere og kontrollere den fattige del av befolkningen.

\section{Blaagaard Skolelærerseminarium}

I siste halvdel av syttenhundretallet foregikk det et omfattende arbeid i Danmark for å bedre skolevesenet. Som del av dette fikk Den store skolekommisjonen i 1789 til oppgave å opprette lærerutdanning og å utarbeide en ny skolelovgivning. ${ }^{32} \mathrm{Opp}-$ rettelsen av det statlig finansierte Blaagaard Skolelærerseminarium i 1791, med det formål å utdanne lærere, var et av de snarlige resultatene av arbeidet $\mathrm{i}$ kommisjonen.

26 Instrux for samtlige Informatorer 1791, \$19, $234 \mathrm{MK}$, RAD.

27 Instrux for Lære-Mødrene 1791, \$ 4, $234 \mathrm{MK}, \mathrm{RAD}$.

28 Ibid.

29 Instrux for samtlige Informatorer $1791, \$ 32,234 \mathrm{MK}, \mathrm{RAD}$.

30 Instrux for samtlige Informatorer $1791, \$ 8,234 \mathrm{MK}, \mathrm{RAD}$.

31 Instrux for samtlige Informatorer 1791, $\$ 16,234 \mathrm{MK}, \mathrm{RAD}$.

32 Ingrid Markussen, "Læreruddannelsens første tid - 1791 til ca. 1830", i Karen B. Braad et al., - for at blive en god loerer: Seminarier i to århundreder, bind 1 av Dansk Loreruddannelse (Odense: Selskabet for Skole- og Uddannelseshistorie/Syddansk Universitetsforlag, 2005), 33. 
Det mer langsiktige resultatet var skolelovgivningen som kom i $1814 .^{33}$

Blaagaard var blitt etablert etter tysk mønster med internat for seminaristene. Seminariet ble igangsatt med 14 elever, og antallet økte til opp mot 40. Fra begynnelsen var undervisningsfagene religion ( 6 timer pr. uke), dansk (2t), historie og geografi (2t), naturhistorie og naturlære (2t), regning og matematikk (6t), katekisasjon (6t), musikk (8t) og skriving (2t). Seminariet så det som sin oppgave å gi seminaristene opplæring som skulle sette dem i stand til å spe på inntekten i de periodene det ikke var skole. Slikt arbeid kunne være landbruk, biavl eller hagedyrking. Her finner vi nedfelt ideene fra kameralismen, som Markussen påpeker, med forbindelser mellom landbruk og skole. Det fantes også andre måter å skaffe seg inntekter på som var mindre ansett, for eksempel som omvandrende musikant. ${ }^{34}$

Undervisningen for elevene i seminariets øvingsskole, Blaagaard Børneskole, åpnet i 1792 med 12 elever i en klasse. Disse hadde, etter ide fra Reventlow, 20 timer i uken. I disse inngikk religion (6t), bibelhistorie (2t), skriving (2t), regning (2t), syllaberen (staving) og allmennyttige kunnskaper (4t), og lesing (4t), senere ble en time brukt til sang. Øvingsskolen ble i 1795 utvidet fra en til to klasser. Om det var elever fra Vaisenhuset som utgjorde denne andre klassen vet vi ikke. Med det antall barn som bodde på Vaisenhuset skulle det i så måte ha vært grunnlag for en langt mer omfattende øvingsskolevirksomhet.

\section{Hvordan var omsorg og utdanning for fattige og foreldreløse barn tenkt re- alisert gjennom en forening av de to institusjonene?}

På tidspunktet for sammenslåing hadde Blaagaard Skolelærerseminarium vært i drift i kun få år. Det var inspirert av seminariet i Kiel som var blitt etablert i 1781. I Kiel var seminariet samlokalisert med Vaisenhuset og guttene der ble undervist av seminaristene. Når det kun er guttene som nevnes, kan det bety at det ikke ble tatt inn jenter. I seminarienes første tid var det et ønske om å legge dem i nærheten av en høyere undervisningsinstitusjon for å få lærerkrefter og tilsynsmenn derfra. Det var også et ønske om å forene det med en oppdragelsesanstalt for å gi elevene øvelse i deres tilkommende yrke. Når Kiel ble valgt som sted, var det fordi en her kunne få forstander og lærere fra universitetet og at seminaristene kunne få øving i undervisning. ${ }^{35}$ Planen for seminariet i Kiel var blitt skaffet til veie av Reventlow og lagt til

33 Året 1814 ble det til sammen vedtatt 5 skoleforordninger. En av disse gjaldt for landdistriktene i Danmark, en annen for kjøpstedene og en tredje for København. De to øvrige gjaldt for Slesvig og Holstein og for jøder i kongeriket; Christian Larsen, Erik Nørr og Pernille Sonne, Da skolen tok form: 1780-1850, bind 2 av Dansk skolehistorie: Hverdag, vilkår og visioner gennom 500 år, red. Charlotte Appel og Ning de Coninck-Smith (Århus: Århus universitetsforlag, 2013), kapittel 7. Dette var samme år som Danmark tapte Norge til Sverige. En egen skolekommisjon var blitt opprettet for Norge 1811. I Norge kom den første skoleloven etter unionsoppløsningen i 1816; jfr. Torstein Høverstad, Norsk Skulesoga: Det store interregnum 1739-1827 (Kristiania: Steenske forlag, 1918), kapittel XI og XII. For situasjonen i Norge for øvrig, se Tone Skinningsrud, Fra reformasjonen til mellomkrigstiden: Framveksten av det norske utdanningssystemet (Tromsø: Universitetet i Tromsø, 2013). http://hdl.handle.net/10037/5208 (lastet ned 1. oktober 2014) og Liv Helene Willumsen, "Trondenes Seminarium: Et lærdomsmiljø grunnlegges," Nordic Journal of Educational History 1, no. 1 (2014), 45-58. Skinningsruds arbeid omfatter framveksten av det norske utdanningssystemet fra reformasjonen, og utgjør et interessant supplement til den nyskrevne danske utdanningshistorien innenfor det tidsrommet helstaten Danmark-Norge eksisterte. Willumsens arbeid viser grunnleggelsen av det første offentlige lærerseminaret i Norge, etablert på Trondenes i 1827.

34 Markussen (2005), 46-7.

35 Joakim Larsen, Bidrag til den danske skoles historie 1784-1818 (København: Unge Pædagoger, 1984 [org. 1893]), 35, 37. 
grunn for organiseringen ved Blaagaard. Ønsket om å forene en oppdragelsesanstalt med seminariet i København hadde ikke fătt tilslutning. Den første tiden etter etableringen av Blaagaard kom det elever fra den nærmeste barneskolen for å bli undervist av seminaristene. I 1792 ble det satt i gang en egen øvingsskole ved seminariet. ${ }^{36}$

Clausen som var førstelærer ved seminariet, fungerte i praksis også som forstander og regnskapsfører. ${ }^{37}$ Han var i tillegg en av de to lærerne som hadde oppsyn med øvingsskolen ved seminariet. ${ }^{38}$ Det betød at han satt inne med en omfattende oversikt over de ulike sider ved driften av Blaagaard. Utdannelsen hadde Clausen fra seminariet i Kiel. Her hadde han også virket som lærer. Clausen hadde derfor førstehåndskjennskap til en organisering der seminariet og vaisenhuset var samlokalisert.

Organiseringen ved Vaisenhuset i København og Blaagaard hadde det til felles at det var internatdrift begge steder. Å samlokalisere de to institusjonene kunne bety økonomisk gevinst i form av driftsfordeler. Imidlertid var det også forskjeller som ikke var uproblematiske. Aldersgrupperingen var ulik. Mens Vaisenhuset var en institusjon for barn og unge, var Blaagaard en institusjon for unge voksne. Både jenter og gutter bodde på Vaisenhuset, mens seminaristene utelukkende var unge menn. Innholdet i undervisningen og metodene var i følge forslaget det samme ved begge institusjonene. Det ble allerede i 1690-årene satt i gang pedagogisk utdanning og praktisk opplæring av guttene i vaisenhusskolene. Det ble oppfattet som viktig at det enkelte menneskets trosforståelse skulle sette spor i sosiale handlinger og at sosial aktivitet bygde på en bærekraftig privatøkonomi. Derfor fikk de pietistiske skolene i Tyskland til oppgave også å gi undervisning i fag som forberedte for et virksomt voksenliv. Dette innbefattet fag som lesing, religion, elementær skriving, regning med innsikt i geometri, historie, geografi, naturfag og praktiske håndverksfag. Dermed ble det også stilt betydelige krav til lærerne. ${ }^{39}$ Gjennom arbeidet til Francke, var ifølge Markussen, prinsippet om en lærerutdanning skapt. Hun framholder videre at det er tenkningen i det tyske pietistiske skoleprogrammet som "mange årtier senere slår igennem i Danmark - som et udslag af en oplysningspræget pædagogik, der af få ville blive betegnet som pietistisk." ${ }^{40}$ Her i kan noe av forklaringen ligge når Clausen argumenterte med at undervisningsinnholdet og metoden ved Blaagaard og Vaisenhuset hadde så mye til felles.

Markussen betoner også forholdet mellom skolereformene og de store endringene i landbruket. ${ }^{41}$ Sist på syttenhundretallet ble landbruket vurdert som den viktigste naturressursen i Danmark, og et av spørsmålene var hvordan man kunne sette bøndene i stand til å dyrke jorden i tråd med de nye landbruksfaglige teoriene. Forslaget om å kvalifisere lærerne var blitt tatt opp i Den lille Landbokommisjonen, og i 1786 hadde denne framsatt forslag for regjeringen om å opprette seminarieutdanning. Forslagsstiller var greve Ludvig Reventlow (1751-1801), og det ble sendt på høring til stiftsøvrigheten på Sjælland, det vil si hos biskop Nicolai Edinger Balle (1744-1816). Reventlow og Balle hadde begge plass i Den store skolekommisjonen,

36 Markussen (2005), 81-2.

37 Ibid., 35.

38 Ibid., 81.

39 Ibid., 23.

40 Ibid.

41 Markussen (1995); Markussen (2005), 25-7. 
og de representerte datidens to pedagogiske leire. Biskop Balle ble regnet som en moderat-konservativ talsmann for reformer på strengt kirkelig grunnlag, Reventlow som tilhenger av tidens fremskrittsideer og filantropist. De sistnevnte var i hovedsak tyskere eller folk som sto den tyske kolonien nær. Reventlow ville ikke bare at skolen skulle gi en bestemt kunnskapsmessig kvalifisering, men også et bestemt holdningsmessig innhold. Han ønsket en klasseundervisning som involverte alle, ikke som i den gamle katekisasjonen der læreren hadde oppmerksomheten rettet mot en og en elev. ${ }^{42}$ Reventlow ville også innskrenke det geistlige tilsynet med skolen, og delvis la det erstatte av skoleinspektører og skolekommisjoner. ${ }^{43}$ Inspirasjonen kom fra tysk reformpedagogikk og var i tråd med naturrettens likhetstenkning. Biskop Balle blir gjerne regnet som Reventlows meningsmotstander. Balle hadde studert i Leipzig og i Göttingen, og han hadde vært professor ved København universitet. Han ville i utgangspunktet forbedre skolen på det bestående grunnlaget, og ønsket ikke skolelærerseminarier etter modell fra Kiel. Balle ville heller at lærere skulle utdannes hos de lokale prestene og var derfor tilhenger av mindre prestegårdsseminarier.

Vi har tidligere sett at Vaisenhuset hadde privilegier når det gjaldt utgivelser av bibler og salmebøker. Trykkeprivilegiene innebar at de skulle være alene om å trykke Danske Bibler og Nye Testamenter med alle slags skrifter og i alle slags formater. Trykkeriet må ha hatt en sentral plass og vært god inntektskilde. Dette underbygges av et kongelig skriv fra 1740. Det inneholder en direkte advarsel til de som trykte bøker Vaisenhuset hadde monopol på. Det framgikk videre at Vaisenhuset, i tillegg til barna der, også forsynte mellom 50 og 60 barn utenfor huset med bøker. Dette, ble det framholdt, var utgifter som byens boktrykkere ikke hadde. Om noen skulle falle for fristelsen å trykke eller innføre slike bøker, måtte de påregne en bot på to tusen Riksdaler, enten til Vaisenhuset eller til annen gudelig virksomhet. I tillegg ville bøkene bli konfiskert. Med trykkeri, bokhandel og apotek har Vaisenhuset sannsynligvis stått seg godt økonomisk. ${ }^{44}$

Vi skal her se nærmere på argumentasjonen til førstelærer Clausen for å samlokalisere de to institusjonene. ${ }^{45}$ Det første han søkte å avklare var hva Vaisenhusets beste besto i, og om dette var knyttet til et bestemt sted. Han ville altså undersøke om virksomheten var så sterkt knyttet til huset den var lokalisert til at den ikke lot seg gjennomføre på alternative steder. Clausen ga en grundig utlegning av dette, med referanser til den opprinnelige fundasen for Vaisenhuset. Han konkluderte med at Vaisenhusets beste ikke var uadskillelig forbundet med en bestemt bygning, men innebar at barna fikk god undervisning og oppdragelse på det sted hvor det etter omstendighetene best kunne skje. ${ }^{46}$

Clausen argumenterte altså for at virksomheten ikke var bundet til de opprinnelige bygningene. I utbroderingen av Vaisenhusets hensikt gikk han inn på den undervisningen og oppdragelsen som var nedfelt i Forordningene av 1727:

42 Markussen (2005), 29.

43 Larsen, Nørr og Sonne (2013).

44 Skriv fra Kong Christian 6. vedrørende trykkeprivilegier, 1740, RAD.

45 Forslag fra Clausen, 18de Sept, 1795, 234 MK, RAD.

46 Ibid. 
At [...] Ungdom bliver opfostret i Gudsfrÿgt, og tillige opdraget i de Videnskaber, hvoraf beqvem(m)e Personer kan tages til Konster, Haandværker og andre Forretninger [...] Ungdom som heraf skal have frie Underholdning, sömmelig og vel maae blive opdragen; saa have I Eder dette som Hoved-Værket i Særdeleshed at lade være angelegen, og med største Omhue og Flid derhen at see, at disse Börn i Guds sande Frÿgt og saliggörende Lærdom, samt udi Læsen, Skriven og Regnen, grundig og vel vorder underviist. ${ }^{47}$

Clausen framholdt at de økonomiske midlene verken måtte brukes til unødvendige lønninger eller bygninger. Han viste til bestemmelsen om inntak, at det heller ikke skulle være overflødige penger i kassen så lenge det fantes forlatte barn. En samlokalisering ville derfor kunne gi flere fattige og foreldreløse barn og unge et godt oppvekst- og utdanningstilbud.

Etter å ha klarlagt at hensikten var det overordnete, gjorde Clausen så rede for midlene..$^{48}$ I disse inngikk Vaisenhusets foresatte, lærere og andre nødvendige personer, bygninger, føde, klær, bøker etc. Videre poengterte han at det aldri hadde vært meningen at midlene skulle være uforanderlige. Neste punkt var spørsmålet om Vaisenhuset kunne lokaliseres utenfor byen og forenes med Blaagaard. Her foreslo han hvordan kommisjonen kunne ta hånd om det økonomiske. Trykkeriet kunne flyttes ut av byen, bokhandelen burde ha lokaler i byen, mens apoketerprivilegiene kunne bortforpaktes. I tillegg kunne tomtegrunnen selges, med en så attraktiv beliggenhet ville den gi en god pris. ${ }^{49}$

Dernest framholdt Clausen at barna var det desidert viktigste. ${ }^{50}$ Han argumenterte med at de utenfor byen ville få renere luft, bedre plass og et miljø som ville være helsemessig å foretrekke. På Blaagaard kunne de også få et jordstykke til å dyrke. Mens informatorene hadde hatt en sentral rolle når det gjaldt å være til stede sammen med og holde oppsyn med barna, brakte Clausen inn den positive betydning yrkesgruppen lærere ville kunne ha. Om informatorene ble byttet ut med utdannede seminarister, ville dette medføre økte utgifter. Hva som skulle føre til disse økte utgiftene sa han ingenting om, men han framholdt at de kunne tjenes inn på andre områder. Clausen slo altså fast at Blaagaard var egnet som Vaisenhus. ${ }^{51}$ Blaagaard var innrettet med tilstrekkelig plass både for vaisenbarna og for seminaristene. I tillegg anførte han en rekke fordeler ved en samlokalisering. Det første gjaldt økonomi. Ved å forene de to stiftelser ville en kunne spare inn stillinger. Det ville bare være behov for en portner, vekter, gårdskar, spisemester, syngemester, tegnemester og en som underviste i hagedyrkning. Dugelige skolelærere fantes på stedet. Deretter kom han inn på de forhold som omfattet selve undervisningen. Seminaristene skulle undervises og undervise i det samme som Vajsenbarna skulle lære.

Mye var også felles når det gjaldt hvordan det skulle undervises, og det viktigste var at undervisningen måtte appellere til forstanden. Han siterte fra fundasen som karakteriserte den undervisning der de unge ble tvunget til å resitere utenat fra bøker

47 Forordninger $1727 \mathrm{~d}(\mathrm{en}) 21 \mathrm{Juli} \$ 3$ og $\$ 13$, her sitert fra Clausens forslag, 18de Sept: 1795, $234 \mathrm{MK}$, RAD.

48 Forslag fra Clausen, 18de Sept, 1795, 234 MK, RAD.

49 Ibid.

50 Ibid.

51 Ibid. 
for misbruk, og som slo fast at mange gikk ut av skolen uten å ha lært det som har vært undervist:

\begin{abstract}
En stor Deel af dem aldrig faar nogen ret Kundskab og Forstand om det, som de med Möisommelighed have lært, mange endog i aldrende Aar, med deres Uvidenhed give tilkjende, at de udi Skolen ingen fast Grundvold har lagt i den Lærdom som de ere underviste udi; andre blive kjedsommelig ved Skolegang, og forlade Skolen, saa at der er faae som oppnaae det Maal, at de formedelst deres gode Venner og ved den tilvoxende Alder erlange den rette Nÿtte af det, som de i Skolen udi deres Ungdom haver lært. ${ }^{22}$
\end{abstract}

I stedet poengterte Clausen at den alternative undervisningsmetoden som skulle anvendes ved Vaisenhuset var den samme som nå ble anvendt ved seminariet..$^{53}$ Denne gikk ut på at læreren forklarte barna på den korteste og beste måten hva de skulle lære, og så gjentok lærestoffet som spørsmål og svar så lenge at barna kunne begripe det som var blitt undervist. Denne framgangsmåten var i tråd med den som framkom i biskop Balles lærebok. ${ }^{54} \mathrm{Og}$ om dette ikke var tilstrekkelig, ville innlæringen kunne hjelpes ved bruk av etterlesing. I instruksen for læremødrene omhandlet en av paragrafene "overlæsning" til dagen etter. Denne skulle skje etter at barna kom fra aftenbønnen som begynte klokken sju, og finne sted under tilsyn av læremoderen. ${ }^{55}$

Clausen framholdt at det ved Vaisenhuset hadde vært mangel på lærere helt siden opprettelsen. ${ }^{56}$ De som hadde sitt virke som informatorer var ofte unge menn, teologiske kandidater, som i påvente av prestekall arbeidet midlertidig som lærere. Clausen viste til at stifteren hadde klaget over at det fantes så få blant studentene som var tilstrekkelig dyktige i å undervise. ${ }^{57}$ Vaisenhusets lærere skulle utdannes gjennom undervisning av biskopen og hoffpredikanten, og om dette ikke var tilstrekkelig, skulle en søke etter andre egnede personer som selv hadde den nødvendige praksis. Ved å vise til dette, fikk Clausen fram at ordningen som var nedfelt i 1727, skyldtes mangelen av et skolelærerseminarium..$^{58}$ Det var i Halle blitt opprettet lærerutdanning i tilknytning til virksomheten ved Vaisenhuset. Når et slikt seminarium nå var blitt opprettet i København, var det i følge Clausen naturlig at man tok lærere herfra, slik vi også har sett at det ble gjort i Kiel. Argumentet for å bruke utdannede seminarister, var at de var i stand til å motvirke ensformighet gjennom å være menn med utmerkede kunnskaper, erfaring, lyst og gaver i pedagogisk henseende. Han viste altså til seminaristenes egnethet. Han framholdt videre at det for Vaisenhusets lærere kunne være gavnlig å ha en anstalt til lærerens dannelse i nærheten, hvor de etter tid og leilighet kunne overvære undervisningen. Her så han altså at Blaagaard hadde potensiale for det som senere er blitt omtalt som etter- og videreutdanning. Clausen argumenterte også med at det kunne skaffes vikarer fra seminariet. Når en av lærerne forlot Vaisenhuset, ble syk eller hadde fravær av andre grunner, kunne en

52 Ibid.

53 Ibid.

54 N. E. Balle, Lerebog i den Evangelisk-christelige Religion indrettet til Brug i de norske Skoler, (Christiansand: O.P. Moe, 1834 [org. 1791]).

55 Instrux for Lære-Mødrene 1791, § 9, $234 \mathrm{MK}, \mathrm{RAD}$.

56 Forslag fra Clausen, 18de Sept, 1795, 234 MK, RAD.

57 Ibid.

58 Ibid. 
av de eldre og dugelige seminaristene påta seg undervisningen og tilsynet. Clausen så også for seg at man blant Vaisenbarna kunne rekruttere unge gutter til seminarieutdanningen. ${ }^{59}$ Argumentasjonen hans kan tyde på at det hadde vært rekruttert seminarister som ikke ble ansett å være skikket for utdanningen. Det ville man unngå, om man i stedet kunne ta inn unge menn som allerede var kjent ved seminariet. Man ville da kunne innestå for at disse hadde de forkunnskaper og den egnethet som var ønskelig. I den danske lærerutdanningshistorien omtaler Markussen selve utvelgelsen til seminaret som kanskje det svakeste ledd. ${ }^{60}$ I et eget kapittel om de første seminarister gir hun bilde av en sammensatt gruppe. Den rommer både menn i alderen 25-30 år med bred yrkeserfaring og 18-20-åringer uten annen erfaring enn den de hadde fra arbeidet hjemme på gården. Hun kommenterer at noen av seminaristene var for gamle til å la seg påvirke og at andre var for skolefremmede. De fleste hadde umiddelbart før opptagelsen fungert som lærere i private eller offentlige skoler. Hun skriver også at lærerne etter endt utdanning, fikk muligheter for biinntekter gjennom å gi ekstraundervisning til halvvoksne sønner av bondestanden som ville inn på seminariet. Dette kan tyde på at det etter hvert ble innført opptaksprøver.

Clausen tok også opp undervisningen og oppdragelsen av jentene ved Vaisenhuset. ${ }^{61}$ Helt fra begynnelsen hadde Vaisenhuset i København vært en institusjon også for jenter. De hadde fătt den samme skoleundervisning som guttene i fagene lesing, skriving og regning. I tillegg var de blitt opplært av læremødrene slik at de skulle bli i stand til å forsørge seg selv. Clausen tok til orde for å endre på dette. ${ }^{62}$ Han forslo at jentene kunne komme til pleieforeldre på landet, gjerne i grupper på tre eller fire. Han framholdt videre betydningen av å være nøye med valg av disse. Som pleieforeldre så han helst gode gifte skolelærere som selv kunne innestå for at ikke noe ble forsømt ved undervisningen og oppdragelsen. Mens skolelæreren skulle stå for den boklige undervisningen, skulle lærerens kone sørge for at jentene ble opplært til husholdningsdrift og håndarbeid. Dette forslaget til endring har sannsynligvis vært foranlediget av et av de argumentene som hadde vært fremmet mot en sammenslåing. Juristen Jacob Gude (1754-1810), som både var inspektør ved Vaisenhuset og sekretær i Misjonskollegiet, hadde begrunnet sitt syn mot en sammenslåing "Efterdi Vaisenhusets Pigebørn vare i den kritiske Alder og Seminaristene i den fyrige Alder" ${ }^{63}$ Få år senere ble det å bo hos pleieforeldre den alminnelige ordning for alle Vaisenbarna, både jenter og gutter. ${ }^{64}$

\section{Konklusjon}

Gjennom å undersøke forbindelsen mellom Vaisenhuset i København og Blaagaard Skolelærerseminarium har det vært mulig å utsi på hvilken måte kjønn og tilhørighet til stand var avgjørende for hva slags lærdom som var tilgjengelig for jentene og guttene ved Vaisenhuset. De ideologiske og pedagogiske forhold ved institusjonen hadde vært i endring i årene forut for sammenslåingen. I 1789 var det blitt tatt initi-

59 Ibid.

60 Markussen (2005), 71-6.

61 Forslag fra Clausen, 18de Sept, 1795, 234 MK, RAD.

62 Ibid.

63 Larsen (1893/1984), 78.

64 Markussen (2005), 33; Exner (1881), 92-102; Ottesen (1927), 89-91. 
ativ til å gjøre endringer i undervisningsplanene ved Vaisenhuset. ${ }^{65}$ De nye planene skulle stemme overens med "den herskende Forestilling om, at med større Kundskabsmeddelelse vilde ogsaa Menneskeaanden forædles”. ${ }^{66}$ Fagkretsen skulle utvides og guttene skulle nå også lære om fedrelandets forfatning og filosofi. Siktemålet med undervisningen i filosofi og religion skulle være å bibringe barna sunne fornuftige og bibelske religionsinnsikter forbundet med sann opplysning og praktisk kunnskap. Undervisningen skulle også forbindes til menneskelige og borgerlige plikter. ${ }^{67}$ For å styrke yrkesutdannelsen skulle det komme håndverksmestere og lære guttene snekkerarbeid, dreiing, billedhuggerarbeid og båndveving. I forhold til Bulls og Markussens teori, kan det se ut til at guttene skulle få sin opplæring mer i tråd med evner og interesser enn utelukkende ut fra stand. Guttene fra Vaisenhuset kom i så måte til å skille seg fra gutter flest, ved at det ikke var standstilknytningen som ble avgjørende for hva slags lærdom de ble til del. Vaisenhuset disponerte over store ressurser, både økonomisk og menneskelig, og det ser ut til at disse var blitt satt inn når det gjaldt å forberede guttene til voksenlivet. Også for jentene i Vaisenhuset var kunnskapstilegnelse ansett som sentralt og viktig. Det ble derfor satset på gode lærekrefter i form av læremødre til å undervise jentene. Heller ikke for disse var det standstilhørelse som ble avgjørende, men anlegg, interesser og ferdigheter innenfor et forholdsvis bredt felt. Omkring 1790 var det blitt tilsatt en ny læremoder for å styrke jentenes utdannelse, blant annet i skreddersøm samt gi spesifikk kunnskap i vasking, stryking, matlaging, gulvvask og rengjøring.

Hva var så Vaisenhusets tiltenkte rolle i det nye seminaret? Den lærerutdanning som var blitt igangsatt ved Blaagaard var en ny type institusjon i den dansk-norske unionen. Vaisenhuset, som var en veletablert institusjon kunne både gå inn med økonomiske midler i forhold til seminaret og det kunne bidra med elever som seminaristene kunne øve seg på å undervise. Blant vaisenhusets unge gutter kunne det også rekrutteres kandidater til seminaret. Det vil si at det for disse guttene åpnet seg ytterligere en yrkesvei. Det framkom imidlertid innvendinger, framsatt av biskop Balle og Vaisenhusets inspektør Gude. Biskop Balles innvending gikk på forslaget om å bruke Vaisenhuset som øvingsskole for seminaristene. Han mente at en slik ordning ville være i strid med fundasen og at det ville gjøre barna til "Læreklude for Seminaristene". ${ }^{68}$ Inspektørens innvendinger gikk på at det kunne bli for tette forbindelser mellom jentene ved Vaisenhuset og de mannlige seminaristene. Denne bekymringen ble besvart av Clausen med å foreslå at jentene kunne flytte til pleieforeldre for å få undervisning og opplæring. Når det gjelder kjønnsaspektet, ser vi at en forening av de to institusjonene kom til å ekskludere jentene fra Vaisenhusets undervisning. I stedet for å ha bolig og undervisning på Vaisenhuset hvor de skulle få opplæring, skulle disse nå settes bort i forpleining. Virksomheten både ved Vaisenhuset og ved Blaagaard var under kritikk. Motstanderne av Vaisenhuset anså institusjonen som unødvendig, og mente at det var bedre å sette barna ut i pleie til private. Motstanderne av Blaagaard ønsket mindre prestegårdseminarier til utdanning av skolelærere. Fra 1799 opphørte ordningen med Blaagaard som en felles institusjon for seminaret og Vaisenhuset ved at alle barna fra Vaisenhuset ble

\footnotetext{
65 Exner (1881), 66-72.

66 Ibid., 68.

67 Ibid., 69.

68 Larsen (1893/1984), 78.
} 
satt ut i pleie. ${ }^{69}$ Hvordan kunnskapstilegnelsen for jentene og guttene ble, etter at de ble satt ut i pleie, blir i så måte et nytt forhold å etterspørre.

\section{Takk}

Takk til Fondet for Dansk-Norsk Samarbeid for stipendopphold ved Schæffergården i forbindelse med kildestudier i Rigsarkivet København.

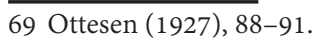




\section{Referanser}

Appel, Charlotte og Morten Fink-Jensen. Da leereren holdt skole: Tiden før 1780. Bind 1 av Dansk skolehistorie: Hverdag, vilkår og visioner gennom 500 år, red. Charlotte Appel og Ning de Coninck-Smith. Århus: Århus universitetsforlag, 2013.

Balle, N.E. Lorebog i den Evangelisk-christelige Religion indrettet til Brug i de norske Skoler. Christiansand: O.P. Moe, 1834 [org. 1791].

Bull, Ida. Kunnskap - hver etter sin stand og sitt kjønn. Utdanning i norske byer på 1700-tallet. Trondheim: Akademika, 2013.

Exner, A. Efterretninger om Det Kongelige Vaisenhus. København: J.H. Schultz, 1881. Den Store Danske. Københavns brande." http://www.denstoredanske.dk/Danmarks_ geografi_og_historie/Danmarks_historie/Danmark_1536-1849/K\%C3\%B8benhavns_brande (lastet ned 1. oktober 2014).

Det Kgl. Vajsenhus 1720-1826. Rigsarkivet i Danmark (RAD).

Høverstad, Torstein. Norsk Skulesoga: Det store interregnum 1739-1827. Kristiania: Steenske forlag, 1918.

Jacobsen, Elizabeth B. "Schönheyders Skolemester-Seminarium i Trondheim: Et forsøk på organisert skoleholderutdannelse ved århundreskiftet 1800.” Hovedoppgave i historie, Universitetet i Trondheim, 1992.

Larsen, Christian; Erik Nørr og Pernille Sonne. Da skolen tok form: 1780-1850, bind 2 av Dansk skolehistorie: Hverdag, vilkår og visioner gennom 500 år, red. Charlotte Appel og Ning de Coninck-Smith. Århus: Århus universitetsforlag, 2013.

Larsen, Joakim. Bidrag til den danske skoles historie 1784-1818, København: Unge Pædagoger, 1984 [org. 1893].

Markussen, Ingrid. Til Skaberens Ære, Statens Tjeneste og Vor Egen Nytte: Pietistiske og kameralistiske idèer bag fremvoksten af en offentlig skole i landdistikterne $i$ 1700-tallet. Odense: Odense Universitetsforlag, 1995.

Markusssen, Ingrid. "Læreruddannelsens første tid - 1791 til ca. 1830.” I - for at blive en god loerer: Seminarier $i$ to århundreder. Bind 1 av Dansk Loreruddannelse, red, Karen B. Braad, Christian Larsen, Ingrid Markussen, Erik Nørr og Vagn Skovgaard-Petersen. Odense: Selskabet for Skole- og Uddannelseshistorie/Syddansk Universitetsforlag, 2005, 15-130.

Ottesen, Chr. Det Kgl. Vajenhus gennem to hundrede aar. København: Haase \&Søn, 1927.

Missionskollegiets arkiv (MK). Rigsarkivet i Danmark (RAD).

Skinningsrud, Tone. Fra reformasjonen til mellomkrigstiden: Framveksten av det norske utdanningssystemet. Tromsø: Universitetet i Tromsø, 2013. http://hdl.handle. net/10037/5208 (lastet ned 1. oktober 2014).

Skjelmo, Randi. "Utdanning av lærere for det nordlige Norge: De tidlige institusjoner i Trondheim 1717-1732." Sjuttonhundratal. Nordic Yearbook for Eighteenth-Century Studies 2013, 39-62.

Store norske leksikon. "August Hermann Francke", http://snl.no/August_Hermann_ Francke. (lastet ned 1. oktober 2014).

Willumsen, Liv Helene. "Trondenes Seminarium: Et lærdomsmiljø grunnlegges." Nordic Journal of Educational History 1, no. 1 (2014), 45-58. 